\title{
Boosting supplier innovations by implementing new promotor roles
}

Key words - Innovation promotor; Innovation champion; Supplier innovation; Innovation implementation

\begin{abstract}
Successfully implemented innovations in firms often benefit from a set of corporate actors who promote such innovations. This is the essence of promotor theory. However, this theory was designed almost five decades ago, when most innovations were still generated internally in a firm's laboratory. In most cases today, suppliers external to the firm play a crucial role in implementing innovations. The question thus arises: do such externally generated innovations actually require the buying firm to have a set of promotors of its own? Relying on a benchmark and the World Café method, our research concludes that a new set of promotors tailored to supplier innovation is needed: (1) the supplier vision promotor, (2) the customer promotor and (3) a diplomatic promotor. Establishing a dedicated team of promotors may be key to boosting innovations coming from suppliers.
\end{abstract}

\section{INTRODUCTION: OBSOLESCENCE OF THE CLASSIC INWARD- LOOKING PROMOTOR MODEL}

I nnovations are defined as successfully implemented ideas that are new to an organization at the time of adoption and pertain to a product, system, process, policy, program, or service (Damanpour, 1987). Effective management of the NPD (new product development) process from the product idea to launch is crucial to ensure that organizations survive and prosper. Following Cooper, there are two main challenges in the innovation management process-selecting the strongest innovation ideas and implementing effective process management (Cooper, 2019; Cooper \& Kleinschmidt, 1987). To ensure effective process management and overcome barriers and resistance within the organization, the innovation process has to be promoted (Goduscheit, 2014). Hauschildt identified the use of innovation promotors as the most important factor for success in innovation project execution (Hauschildt, 2003). He distinguishes three kinds of promotors: the expert promotor (also called the technology promotor) who has specific projectrelated expertise; the process promotor who has organizational know-how; and the power promotor who brings hierarchical power into action (Hauschildt, 2003). Gemünden expanded this trio by adding the relationship promotor, who uses social competences to push innovation forward (Gemünden \& Walter, 1999).

Another crucial aspect in relation to innovation project execution and innovation implementation is supplier involvement. Today, due to increasing competitive pressure, companies are forced to increasingly rely on supplier cooperation (Koufteros, Rawski, \& Rupak, 2010; Wagner,
2012) and on innovations from and developed in cooperation with their suppliers (Dekkers, Chang, \& Kreutzfeldt, 2013). Supplier cooperation within the NPD process provides a variety of benefits, e.g., a shorter time to market, higher product quality, lower project costs, and a higher speed of production (Primo \& Amundson, 2002).

Although most innovations are currently provided by suppliers (Roberts, 2001), a literature review shows that existing innovation execution and implementation methods, such as the use of promotor models or roles, are mainly focused on internally developed innovations. In fact, prior research on innovation promotors has focused mainly on internal innovation, whereas external knowledge exploitation has been largely neglected (Lichtenthaler \& Ernst, 2009), and the role of innovation promotors in interorganizational innovation projects has not been scrutinized (Goduscheit, 2014). The only promotor that touches the boundary between the buying company and the outside world, is the relationship promotor, who is oriented towards customers and other external actors (Goduscheit, 2014). Nevertheless, this relationship promotor only helps the company to obtain more knowledge to improve its internal innovations and promote internal innovations to external stakeholders. The relationship promotor does not focus explicitly on supplier innovations or on how to promote them in the buying company. Another unanswered question in innovation promotor research is whether the promotor roles should become officialized or implemented as informal roles in formal positions (e.g., the "innovation manager") and, if so, how this should be done (Maier, Rück, \& Brem, 2017).

The goal of this study is to close the described research gap by evaluating whether the existing innovation promotors are still valid for supplier innovations or whether adjustments need to be made - or even whether new promotor roles need to be introduced - to meet the needs and characteristics of supplier innovations. Moreover, suggestions are provided for whether and in which formal positions future innovation promotor roles that promote supplier innovations could be integrated.

The following theory section presents a short overview of the existing innovation promotor and champion models and explains the role of the supplier in the NPD process. The subsequent section presents the method and analysis used in this study. To evaluate whether there are any best practices regarding promotors for supplier innovations in the industries, a benchmarking analysis was conducted. The participants were purchasing and innovation management experts from 16 leading companies located in Germany. Analyzing the results revealed that most of the case companies do not use explicit innovation promotors and do not use special methods to handle 
supplier innovations. To further discuss the found results, a World Café method was used as a second technique. The World Café method, which was created by Brown and Isaacs (Brown $\&$ Isaacs, 2005), can be regarded as a specialized form of the conventional focus group approach (Brennan \& Ritch, 2010). Through two combined World Café workshops, the participants-half of whom had participated in the benchmarking exercise and half of whom were newly recruited to complete and balance the sample-designed three new promotor roles. The three developed promotor roles with the highest ratings were as follows: (1) the supplier vision promotor, (2) the customer promotor and (3) a diplomatic promotor. In the second World Café workshop, the participants formulated "job descriptions" for the new innovation promotors containing the proposed main tasks and personal characteristics of the promotors. Through these results, the paper contributes to the innovation management literature by expanding and empowering the established promotor theory by adding new supplier innovation-focused promotor roles. The paper ends with a discussion and conclusion section in which the results and contributions are discussed and further considerations, limitations and complementary ideas are presented.

\section{THEORY: THE INNOVATION PROCESS AND THE NEW RELEVANCE OF SUPPLIER INVOLVEMENT}

Innovation champions and innovation promotors in the NPD process: There are several NPD and innovation management approaches for developing and handling different kinds of innovations within a company. Typically, sequential, multistep processes are used to select and implement innovations. For instance, Lynn et al. describe a conventional NPD process as occurring through idea generation, idea screening, innovation development, testing, and new product launch (Lynn, Morone, \& Paulson, 1996; Williams \& McGuire, 2010). Cooper (2019) identified 20 success factors that drive NPD success. The 20 factors can be divided into three categories: individual innovation-related factors (e.g., the added value of the innovation as perceived by the users), organizational and strategic company-related factors (e.g., management commitment or the organizational culture) and systems and methods that the firm has in place for managing NPD (e.g., gating systems or agile development approaches) (Robert G. Cooper, 2019).

To exploit these success factors within organizations and to implement and launch innovations successfully, using a model of innovation champions or innovation promotors is one common operationalization strategy (Hauschildt, 2003). In the following section, both approaches - the innovation champion and the innovation promotors - will be described in detail.

First, the innovation champion model, introduced by Donald Schon (1963), can be defined as a concept in which a single, outstanding person positively influences the success of an innovation project within an organization through, e.g., hierarchical power, technical and economical expert knowledge (Maier et al., 2017; Rost, Hölzle, \& Gemünden, 2007; Schon, 1963). The innovation champion is characterized by being passionate about a particular innovation project and having the necessary competence and endurance to overcome barriers and resistance to support the innovation implementation (Schültz, 2014). Special success characteristics of a person who takes over the informal role of an innovation champion are expertise, credibility, planning skills, networking skills, sensitivity, objectivity, tenacity, decisiveness, assertiveness and confidence (Buswick, 1990). The champion concept is presented as a monopersonal concept in which the success or failure of the innovation process is attributed to one single person (Gemünden, Salomo, \& Hölzle, 2007).

Second, applying the promotor theory is a strategy to support the implementation of innovations through the use of several innovation promotors. In contrast to the innovation champion approach, which is a monopersonal concept, the promotor model consists of a team of up to four dedicated innovation promotors (Rese, Gemünden, \& Baier, 2013). Innovation promotors are persons who commit themselves with enthusiasm and self-motivation to a new product or innovative idea and therefore take over the informal role to promote this innovative idea or new product and lead it to a successful implementation

\section{Box: Definition of the term "role"}

From a sociological point of view, a "role" is defined as the sum of expectations of a person's social behavior, a socially provided pattern of behavior that can or must be performed in certain situations (Meyer, 1998). From an organizational or business related perspective, a role can be described as an informal set of expectations for the actions an employee takes to perform various functions (Daft, 2003; Elkins, 2019). Whereas a "function", is more formal and is generally defined as the responsibilities of an employee, including the key duties listed in a job description (Daft, 2003; Elkins, 2019).

(Gemünden et al., 2007; Hauschildt \& Kirchmann, 2001).

The Promotor theory was developed by Witte (1977), Chakrabarti and Hauschildt (1989), Walter and Gemünden (2000) and Hauschildt and Kirchmann (2001) and is based on the assumptions that innovations are faced with different kinds of barriers and that different promotor roles-played by different persons who specialize in these roles - are needed to overcome them (Chakrabarti \& Hauschildt, 1989; Hauschildt \& Kirchmann, 2001; Rese et al., 2013; Walter \& Gemünden, 2000; Witte, 1977). The promotor roles are defined by the type of barriers they help overcome, the type of power bases on which their influence is grounded, and their specific type of behavior. (Gemünden et al., 2007; Rese et al., 2013).

Figure 1 shows the promotor model, which contains four specialized promotor roles - the expert promotor (sometimes called the technology promotor), the power promotor, the process promotor and the relationship promotor that can act independently from each other or in promotor teams (Gemünden \& Walter, 1999; Hauschildt, 2003).

The core of a promotor team is formed by the power and the expert promotor (Schültz, 2014; Witte, 1977). The expert promotor brings specific technical knowledge to the innovation process, searches for new information, generates new alternatives and assesses existing solutions (Hauschildt, 2003; 


\section{The promotor model ${ }^{*}$}

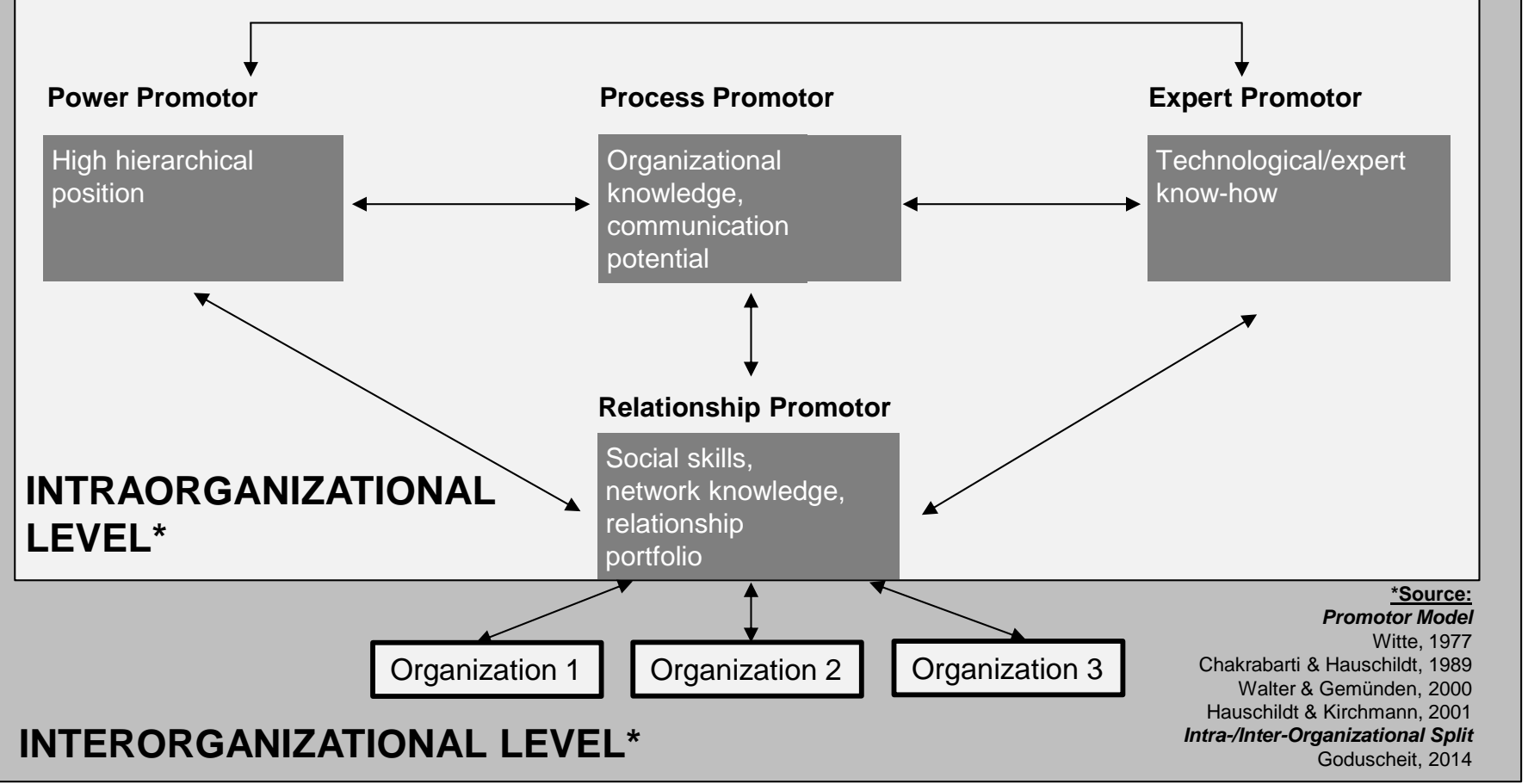

Fig. 1. The promotor model

Hauschildt \& Kirchmann, 2001). The major activities of the expert promotor are using his or her expert knowledge to make technical design contributions to the innovation (Rese et al., 2013; Rothwell et al., 1974) and to help overcome barriers of ability and of "not knowing" the innovation (Gemünden et al., 2007). The power promotor uses hierarchical power to shield the innovation from opposition, formats goals, defines the problem and confirms the strategic fit (Hauschildt, 2003; Hauschildt \& Kirchmann, 2001). The power-promoting role is mostly inhabited by a highly committed senior manager in order to overcome barriers such as "not wanting" to implement an innovation within the company (Gemünden et al., 2007; Rese et al., 2013).

The core team becomes a "troika" when the process promotor is introduced (Hauschildt \& Kirchmann, 2001). The process promotor, usually a committed middle manager, helps overcome bureaucratic and internal administrative barriers by employing an internal organizational network, performing project and interface management and providing information about resources (Gemünden et al., 2007; Hauschildt \& Kirchmann, 2001; Rese et al., 2013).

Finally, Gemünden and Walter introduced a fourth promotor, the relationship promotor. They noted that an increasing number of innovations require cooperation with external partners in the value chain, i.e., with customers or suppliers (Gemünden \& Walter, 1999; Hauschildt, 2003). The relationship promotor plans and controls cooperation with these external partners through the execution of the innovation project and promotes the flow of information (Kirchmann, 1994; Schültz, 2014). The relationship promotor has strong personal ties, especially outside the organization, and helps to overcome barriers related to not knowing external partners and not being able or willing to communicate with them (Gemünden et al., 2007).

Despite the fact that the existence of innovation promotors (and innovation champions) seems to be a crucial success factor for innovation execution (Hauschildt, 2003), it is surprising that in most companies, these positions are either nonexistent or exist only on a strictly informal level (Howell, Shea, \& Higgins, 2005; Maier et al., 2017). That means that in these companies, there is no official "innovation promotor" function, but someone takes over the informal role.

Supplier involvement in the new product development process: As the literature shows, crucial success and blockade factors for innovation project realization and implementation result not only from internal organization but also from collaboration with external stakeholders (Goldberg \& Schiele, 2020; Lambooij \& Koster, 2016; Yoo, Sawyerr, \& Tan, 2015). The most important external stakeholders in innovation project execution within a buying company are suppliers because buying companies receive the most innovations from them (Dekkers et al., 2013). The demand for an ever shorter time to market and the high and specific technological knowledge that is needed to develop new products force firms to increasingly rely on supplier cooperation (Hong, Doll, Revilla, \& Nahm, 
2011; Koufteros et al., 2010; Wagner, 2012). Several studies show that supplier cooperation in the NPD process may provide benefits, e.g., a shorter time to market (Ragatz, Handfield, \& Petersen, 2002), higher product quality or lower project costs and time (Primo \& Amundson, 2002). With the goal of obtaining a greater competitive advantage through supplier cooperation, many companies are adopting ESI (early supplier integration), which is defined as vertical cooperation in which companies involve suppliers at an early stage in the NPD process (Bidault, Despres, \& Butler, 1998; Hoegl \& Wagner, 2005). The contribution of a supplier (e.g., through skills, resources and talents) can constitute a significant advantage in the product development process (He, Keung Lai, Sun, \& Chen, 2014). ESI plays a key role, particularly in terms of increasing the innovative strength of a buying company and the capability of innovation project execution (Fitjar \& Rodríguez-Pose, 2013; Song \& Thieme, 2009; Un, Cuervo-Cazurra, \& Asakawa, 2010).

In addition to pointing out the necessity of including suppliers in the NPD process, innovation research connects the success of interorganizational innovation projects to the existence of transformational leaders, champions and promotors (Fichter, 2009; Rese et al., 2013). However, it appears that the mainly internally oriented promotor and champion models do not fit all kinds of innovations (Gemünden et al., 2007). More precisely (compare with figure 1), the power, expert and process promotors are all designed to be intraorganizational actors. Only the relationship promotor, who is oriented towards customers and other external actors, touches the boundaries of the organization (Goduscheit, 2014; Rost et al., 2007).

However, although the introduction of the relationship promotor shows a growing focus on the environment and external partners of a company (Gemünden et al., 2007), the classic promotor theory, which was introduced more than 45 years ago, no longer fits today's situation, particularly given the observation that currently, the majority of innovations are provided by suppliers (Dekkers et al., 2013; Schiele, 2010). Who in a firm is promoting suppliers who are performing their new role in innovation? The literature notes that although the relationship promotor should be used as a boundary spanner, e.g. for tasks such as importing external knowledge (Gemünden et al., 2007), existing studies focus only on how to promote internal innovation (through internal and perhaps external support) and neglect the promotion of external supplier innovations within the buying company and through the processes of the buying company (Lichtenthaler \& Ernst, 2009). However, our detailed literature review did not find any studies on the promotion of supplier innovations within a buying company. The aim of this study is therefore to close this gap and evaluate whether the existing innovation promotor roles are still sufficient for dealing with supplier innovations, whether adjustments must be made, or even whether new promotor roles need to be introduced.

\section{RESEARCH METHODOLOGY: BENCHMARKING \& WORLD CAFÉ}

To evaluate whether the existing promotor roles are still adequate and whether there are any best practices regarding promotor use for supplier innovations in the relevant industries, a benchmarking analysis was conducted. Benchmarking is defined as the search for best practices in a certain field or in relation to a specific topic, the implementation of which will assist in achieving superior performance (Camp, 1989). Three types of benchmarking can be distinguished: process benchmarking (which this paper applied), product or service benchmarking and strategic benchmarking (Drew, 1997). The aim of this benchmarking study was to evaluate the existing best practices in relation to the company's internal use of innovation promotors for support, the project execution and the implementation of supplier-proposed innovations.

To discuss the results further and create new solutions, a second technique - a World Café workshop-was used. The World Café method was created by Brown and Isaacs (Brown \& Isaacs, 2005) and can be regarded as a specialized form of the conventional focus group approach (Brennan \& Ritch, 2010). According to Schieffer et al., the key purpose of a World Café workshop is to work and think within a group and hence to innovate collaboratively (Schieffer, Isaacs, \& Gyllenpalm, 2004). It is a user-friendly method due to the following characteristics. The participants divide themselves into small groups that come together at different tables. At each desk, one particular aspect of the research problem is discussed with the help of a moderator, who hosts the debate (Hüttinger, Schiele, \& Schröer, 2014). After a predefined period of time (usually 20-45 minutes), the participants are requested to change tables. They can freely choose the table for the next round but may not return to any table where they have already participated. Consequently, each discussion round brings together a new group in a new formation. At the beginning of each round, the moderator shares and summarizes the previous discussion points. This process is repeated until each participant has contributed to every discussion topic (Hüttinger et al., 2014). At the end, each moderator summarizes the results of his table and presents them to the plenum. Frequently, the final step is an evaluation round in which the participants walk around and review the list of results at each table. They rate the aspects at each table with the help of "stickers". In doing so, a ranking of the aspects emerges at each table. The more "stickers" an aspect receives, the more important it is in the eyes of the participants.

\section{ANALYSIS: LIMITED FORMALIZATION AND THE NEED FOR NEW PROMOTOR ROLES}

All benchmarking participants were interviewed using a detailed questionnaire to analyze whether their company uses the promotor model of Witte, Hauschildt and Gemünden (power promotor, expert promotor, process promotor and relationship promotor) or models of other innovation champions (Hauschildt, 2003; Rost et al., 2007).

Sixteen companies participated in the benchmarking (out of 73 invited companies). The participants were experts from 
various leading companies located in Germany. The goal was to devise a participant setup that was as diverse as possible. Therefore, companies with different sizes and from different business sectors were selected. Eight large companies were selected because they are well-known global players, and eight smaller ones were selected because of their innovation power. The company representatives were purchasing managers, innovation managers, or NPD process managers. The benchmarking results are summarized in figure 2 . show that none of the case companies use special methods to differentiate the handling of supplier innovations and internally generated innovations. This practical experience also confirms the findings from the literature review. To discuss these insights from the benchmarking analysis and to further develop them and create innovation promotor roles that fit the "needs" of supplier innovations, the World Café method was used as a second technique.

The superordinate topic of the World Café workshop was the

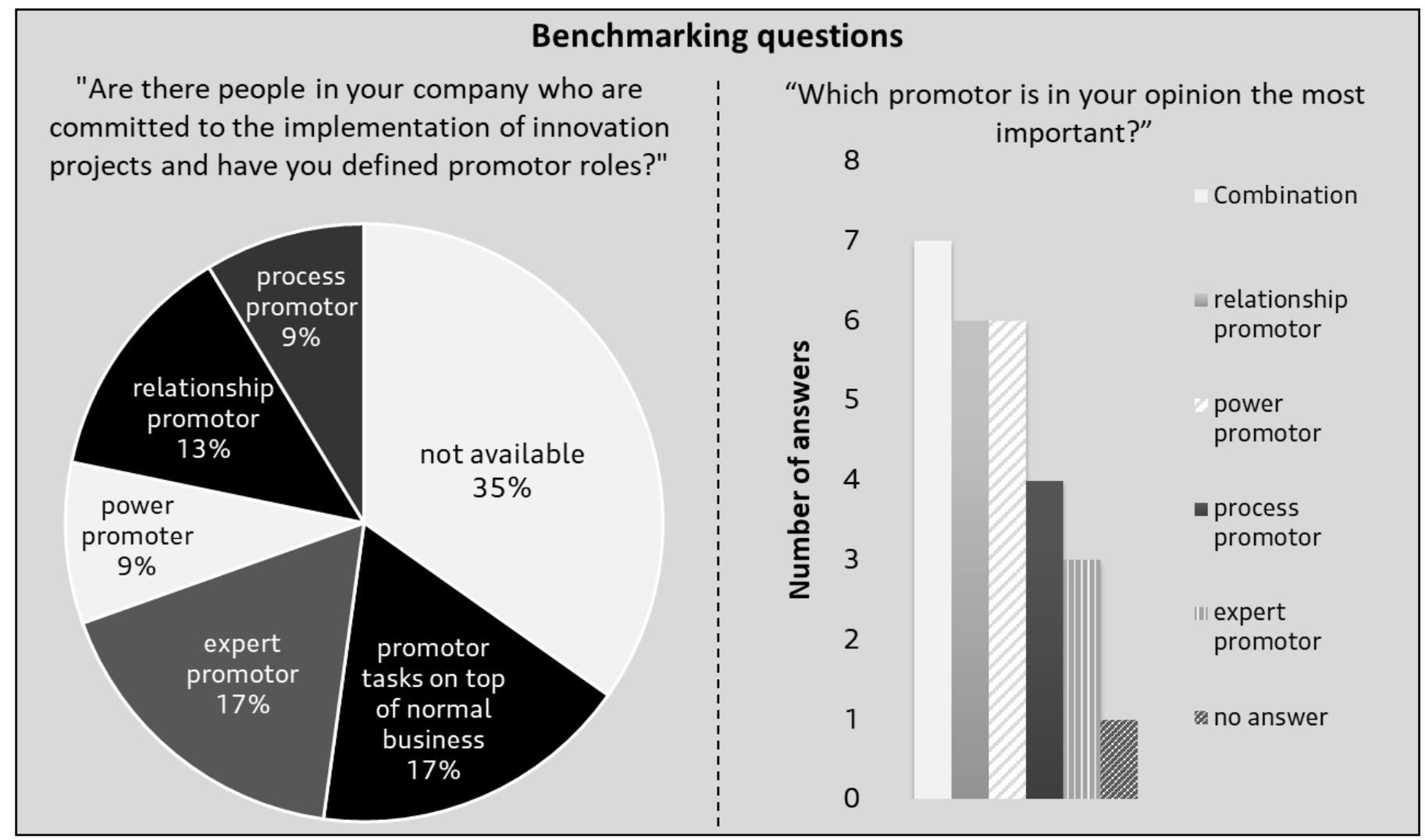

Fig. 2. Results of the benchmarking analysis

When asked whether they use promotors in innovation projects, $35 \%$ of the case companies answered that they do not have specific persons who act as promotor, and another $17 \%$ of the companies said that some employees take over the role of a promotor in addition to their main responsibility and profession. The majority of the $48 \%$ of the case companies that use promotors said that it is most efficient to use a combination of different promotor roles. Additionally, $52 \%$ of these companies said that the explicit use of promotors brings significant advantages to the company (25\% said that there is no advantage gained by using promotors, and $23 \%$ did not track the use of promotors and were unable to give a statement).

Analyzing the results of the benchmarking revealed that none of the companies use formalized promotor functions, and only $48 \%$ of the case companies employ people who focus on the promotor role. The observation that more than half of the companies do not use explicit promotors substantiates the assumption that the existing promotor roles are not entirely helpful, must be questioned, and may be adjusted or replaced. They do not seem to fit the current NPD reality. The results also "evaluation and execution of supplier innovations at buying companies". To investigate this subject, four tables were created, each addressing one of the following subtopics: (1) "innovation clustering and evaluation with a focus on the innovation", (2) "innovation clustering and evaluation with a focus on the supplier", (3) "innovation control with a focus on the success measurement of the innovation and the process" and (4) "innovation promotors". Because the scope of this paper is the use of promotors, only the results of table four are shown and discussed.

Altogether, 15 participants from 12 companies took part; seven of the participants had already participated on behalf of their companies in the benchmarking workshop, and eight were newly recruited to complete and balance the sample. This combination was chosen in order to include both participants who were involved in the creation of the base data and participants who could provide new information. The participants were selected according to their expertise in the areas of innovation management, NPD, and purchasing.

In this study, the standard World Café method was expanded 


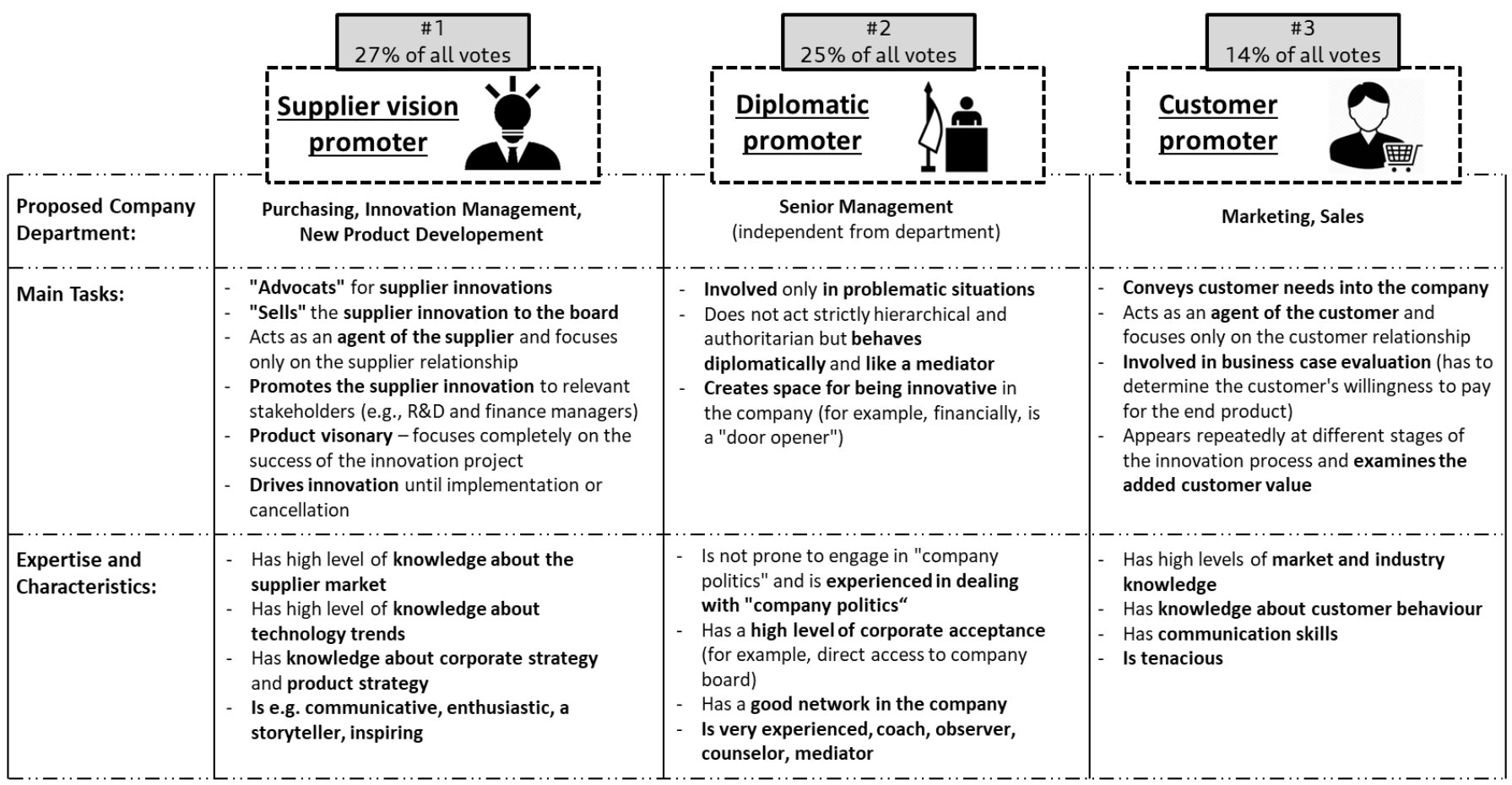

Fig. 3. Results of the World Café workshop - Three new promotor roles

by combining two small World Cafés. In World Café 1 , the moderator at each table showed the relevant consolidated results of the benchmarking referring to the topic at his or her table (the participants at table 4 received the benchmarking results about the use of promotors (figure 2)). In the four short World Café rounds that followed, the participants discussed the benchmarking findings and had the chance to add new aspects and arguments. At the end of the four discussion rounds, the participants decided that new promotor roles are necessary. They identified six possible new promotor roles. At the end of World Café 1, there was a "sticker" evaluation round. Each of the 15 participants received 20 "stickers" (5 for each table) to rate the aspects that were the most important from their perspective. The following three "new" promotors received the highest scores through the "sticker" rating system: supplier vision promotor (product visionary, 27\%); diplomatic promotor (coach, "door opener" and mentor in tricky situations, 25\%); and customer promotor (focused on customer needs, 14\%). None of the classic promotor roles of Witte, Hauschildt and Gemünden (power promotor, technology promotor, process promotor, relationship promotor) found their way into the final discussion list at table 4 (Gemünden \& Walter, 1999; Hauschildt, 2003; Witte, 1973).

After seeing these results, the moderators took the three new promotor roles with the highest ratings to work with in World Café 2. The task in the four discussion rounds of World Café 2 was to determine the personal characteristics of the three "new" promotor roles as well as their proposed main tasks within the organization and the potential department in which they could be located. The results of the World Café is shown in figure 3 .

\section{DISCUSSION: THREE NEW ROLES TO PROMOTE EXTERNAL INNOVATIONS}

In this section, the key findings of this study are discussed, and an overview of the managerial and research implications is provided. This paper presents insights from a benchmarking study and a World Café workshop. Sixteen German companies participated in the benchmarking and shared their know-how about the use of innovation promotors or champions. A notable result from the benchmarking study is that most case companies do not use explicit innovation promotors or use special methods to handle supplier innovations. To discuss the findings further, a World Café method was used, the result of which was that the participants designed three new promotor roles: 1 . the supplier vision promotor, 2. the diplomatic promotor and 3. the customer promotor.

The results show that it is necessary to innovate the existing promotor models. This is not surprising because when the promotor theory was invented more than 45 years ago, nearly all innovations were generated internally rather than together with suppliers. Hence, it was fully sufficient to focus on internal barriers. However, today, the vast majority of innovations are provided by suppliers (Roberts, 2001), so specialized promotors may be needed.

Therefore, it is not surprising that the supplier vision promotor who acts as a kind of supplier innovation advocate, was designed by experts in the World Café workshop and received $27 \%$ of the participants' votes. The supplier vision promotor promotes external innovations to the board and to relevant project stakeholders in the company (e.g., R\&D and finance managers) and drives and supports the progress of the innovation until implementation or cancelation. The name "supplier vision promotor" was chosen because of the 
promotor's product visionary role and complete focus on the implementation success of the external supplier innovation. One of the main tasks of the supplier vision promotor is counteracting the "not invented here" syndrome. The "not invented here" syndrome may occur within the buying company in reaction to external innovations and expresses itself through an attitude of blocking and rejecting anything from the outside world (Katz \& Allen, 1982). The experts from the World Café workshop identified the supplier vision promotor as having strong expertise regarding the supplier market, technology trends and the corporate and product strategies of the buying company. To fulfill the intended tasks, the supplier vision promotor needs to be a storyteller who is communicative, enthusiastic and inspiring. The experts of the World Café workshop proposed implementing the supplier vision promotor role in the formal position of a purchasing manager, an innovation manager or an NPD manager. Furthermore, it is conceivable that the supplier vision promotor could become the explicit promotor for the buyer-supplier relationship. Because through the role, in which the interest of the supplier (by promoting its innovation) is strongly represented, the supplier vision promotor makes a contribution to becoming a preferred customer of the respective supplier. Preferred customer status means that a supplier has awarded selected customers with more favorable treatment and with preferential resource allocation over others (Hüttinger, Schiele, \& Veldman, 2012). Additionally, preferred customer status leads to preferred access to suppliers' innovations, which results in the buying company having substantive competitive advantages in the market (Schiele, 2012).

The diplomatic promotor was designed by the World Café participants as a senior manager who is involved in resolving problematic situations in an innovation management project. Another main mission is creating spaces in the company for being innovative (for example, by providing financial support or acting as a "door opener" to the board or top management). The diplomatic promotor acts like a mentor, coach or even mediator; has a good network within the company; and enjoys a positive reputation. The diplomatic promotor is definitely a person with hierarchical power, which is similar to the power promotor (Hauschildt, 2003; Witte, 1973). However, the profile of the diplomatic promotor is complemented by diplomatic and "company political" skills, which, in interorganizational projects, are assigned as skills of the process promotor (Gemünden et al., 2007; Goduscheit, 2014). Therefore, it appears that the diplomatic promotor is a merger of characteristics from the power promotor and process promotor roles. This merger seems to make sense for supplier innovations because, following the literature in interorganizational settings, the division of labor between various promotors and persons (Chakrabarti \& Hauschildt, 1989) seems to be more challenging, and role accumulation is suggested (in contrast to intraorganizational settings where role specialization seems to be beneficial) (Goduscheit, 2014; Rese et al., 2013).

The third new promotor role, which was designed by experts in the World Café workshop, is the customer promotor. Following the intentions of the experts, the customer promotor is located in the marketing or sales department, and the main intention of this role is to convey customer needs to the company. That the experts see the necessity of introducing the customer promotor fits with the development that due to a perceived increase in competitive pressure, a customer-oriented focus is needed (Appiah-Adu \& Singh, 1998; Desouza et al., 2008). Moreover, the customer promotor should be involved in business case evaluations (to determine the customer's willingness to pay for the end product), appears again at different stages of the innovation process and examines the added customer value. The person who takes over the role has to have a high level of market and industry knowledge, as well

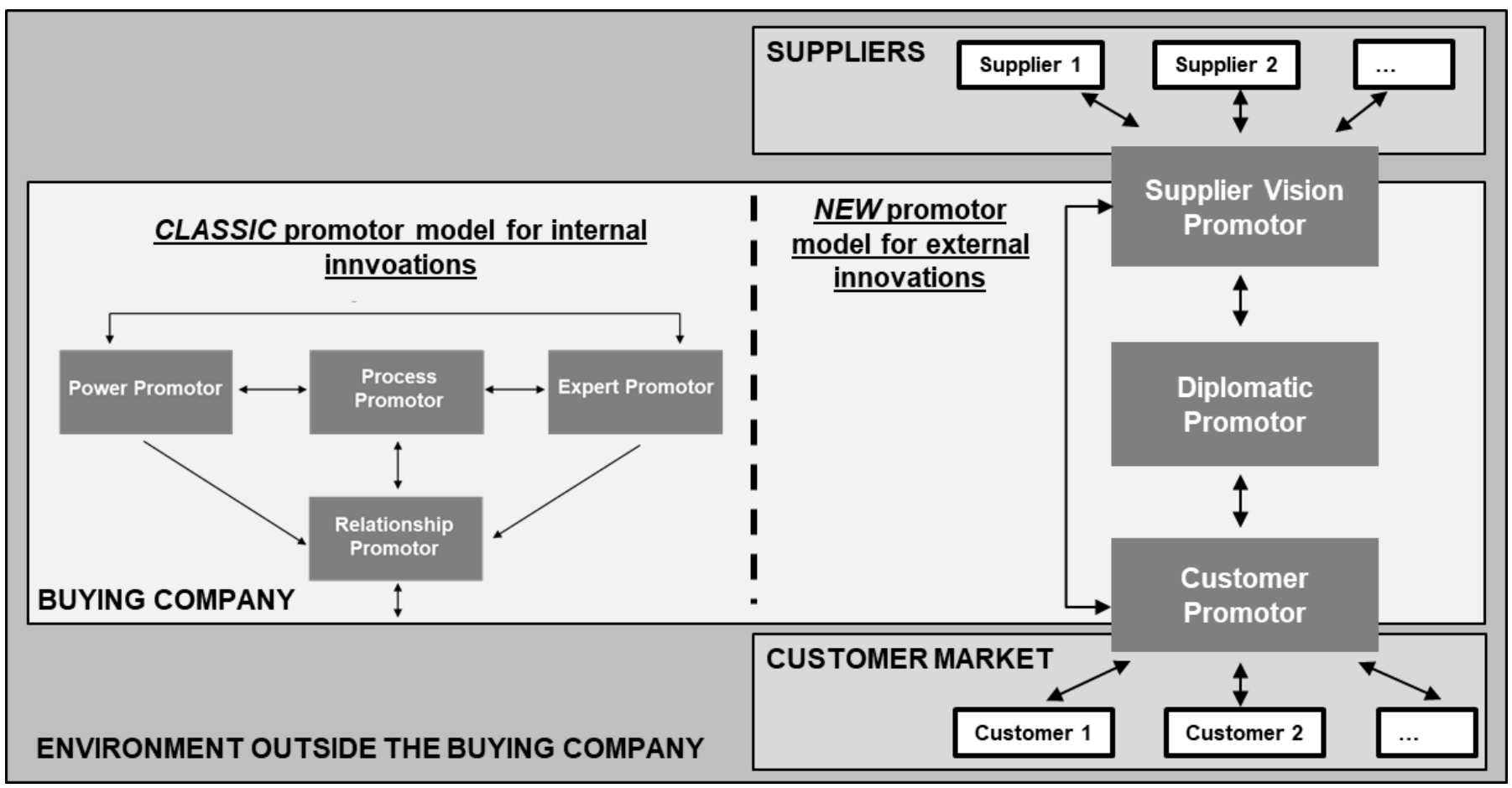

Fig. 4. Interaction of the three new promotor roles with the environment in contrast to the classic promotor roles 
as a strong experience with customer behavior. Essential skills include being communicative and persistent.

Both roles, the customer promotor and the supplier vision promotor, supplement each other very well but cannot be merged into one "relationship" promotor. While one is the agent of the supplier, the other is the agent of the customer. This can mean that there is a productive conflict. The supplier vision promotor brings the innovation into the firm, overcomes internal reservations about external innovation and drives the innovation forward through all company processes, overcoming all obstacles. The customer promotor makes sure that the new product meets the customer's requirements and is sellable. In tricky or conflicting situations, the diplomatic promotor steps in to help implement the project successfully. In figure 4 , the interaction of the three new promotor roles in connection to the promotion of supplier innovations and to the supplier and customer environment is visualized. Based on our findings, we propose using different promotor teams adapted to the respective kind of innovations, one for internally generated innovations - the classic promotors - and one for innovations provided by suppliers - the newly developed ones (compare figure 4).

In addition to the recognized need to renew and adapt the existing promotor roles, the experts in the World Café workshop referred to another crucial point. They mentioned that it is problematic for practitioners that there are no clear suggestions or implementation or introduction guidelines on whether and how to officialize promotor roles within a company. This opinion is also supported by current research; for example, Howell et al. (2005) and Maier et al. (2017) point out that although the existence of innovation promotors (and innovation champions) seems to be a crucial success factor for innovation execution (Hauschildt, 2003), in most companies, these positions are either nonexistent or exist only on a strictly informal level (Howell et al., 2005; Maier et al., 2017). Maier et al. (2017) deals with the question of why and, subsequently, how promotor roles should become officialized or implemented as informal roles in formal positions such as the "innovation manager" (Maier et al., 2017). Their findings show several reasons why such positions might be formally institutionalized, the main one being that doing so reduces "firefighting efforts" in later phases of the $\mathrm{R} \& \mathrm{D}$ process and therefore reduces costs and lead time (Maier et al., 2017).

\section{CONCLUSION AND OUTLOOK}

This paper provides managers with insights in the following ways.

1. Although nearly all innovations are currently provided by suppliers, the classic promotor theory and existing promotor roles focus on internally generated innovations. Therefore, this paper contributes to innovation management research by showing that the expansion and empowerment of the established promotor theory in the direction of the external environment of the firm is necessary.

2. This paper introduces three newly designed promotor roles that are appropriate for the challenges faced when incorporating innovations provided by suppliers. The supplier vision promotor focuses on the specialties of supplier innovations, the customer promotor pays attention to customer demands, and the diplomatic promotor acts as a strong, hierarchical supporter as well as a mentor, coach and sensitive "company politics" mediator.

3. Based on the findings, this paper proposes the use of different promotor teams adapted to different kind of innovations: the classic promotor team (power, expert, process and relationship promotors) for internally generated innovations and the new promotor team (supplier vision, diplomatic and customer promotors) for innovations provided by suppliers. There cannot be only one promotor who addresses the outside world because different stakeholders (e.g., suppliers and customers) require different types and levels of support.

4. This paper gives managers various suggestions about where within the company the new promotors can be integrated or institutionalized and which characteristics the person who takes over one of the promotor roles should have.

To develop the new promotor roles further and ensure that they are adapted to the "needs" of supplier innovations and that they become more customer focused, innovation research should focus more on the concept description of the new promotor roles. Moreover, innovation management research should concentrate on establishing the use of two different promotor teams for the two kinds of innovations - the classic promotors for internal innovations and the new promotors for supplier innovations. Additionally, research on the formalization process, success factors, localization of promotor functions and implementation of informal promotor roles and skills must be extended.

In addition to the results discussed above, there are some limitations associated with this study. The benchmarking was performed with only 16 case companies, which is a small sample size. Both the benchmarking and the World Café workshops were conducted only with German companies; thus, the results may not be generalizable to companies from other countries or continents. In future research, other kinds of companies (e.g., from other countries and continents or with different sizes) as well as more complex interorganizational setups (with more than only two players (buying company and supplier)) should be studied.

\section{REFERENCES}

[1] K. Appiah-Adu, S. Singh, "Customer orientation and performance: a study of SMEs", Management decision, vol.36, no. 6, pp. 385-394, 1998.

[2] F. Bidault, C. Despres, C. Butler, "Leveraged innovation: Unlocking the innovation potential of strategic supply", Houndsmills: MacMillan Press LTD, 1998

[3] C. Brennan, E. Ritch, "Capturing the voice of older consumers in relation to financial products and services", International journal of consumer studies, vol. 34, pp. 212-218, 2010.

[4] J. Brown, D. Isaacs, "The world café: Shaping our futures through conversations that matter", Oakland, USA: Berrett-Koehler Publishers, 2005.

[5] T. Buswick, "Champions of Technology Innovation", Training \& Development Journal, vol. 44, no. 2, pp. 48, 1990.

[6] R. Camp, "Benchmarking. The search for industry best practices that lead to superior performance", Milwaukee: ASQC Quality Press, 1989. 
[7] A. K. Chakrabarti, J. Hauschildt, „The division of labour in innovation management”, R\&D Management, vol. 19, no. 2, pp. 161-171, 1989.

[8] R. G. Cooper, "The drivers of success in new-product development", Industrial Marketing Management, vol. 76, pp. 36-47, 2019.

[9] R. G. Cooper, E.J. Kleinschmidt, "Success factors in product innovation", Industrial Marketing Management, vol. 16, no. 3, pp. 215-223, 1987.

[10] R. L. Daft, Management (6 ed.). Manson, USA: Thomson Learning/SouthWestern, 2003

[11] F. Damanpour, "The Adoption of Technological, Administrative, and Ancillary Innovations: Impact of Organizational Factors", Journal of Management, vol. 13, no. 4, pp. 675-688, 1987.

[12] R. Dekkers, C. M. Chang, J. Kreutzfeldt, "The interface between "product design and engineering" and manufacturing: A review of the literature and empirical evidence", International Journal of Production Economics, vol. 144, no. 1 , pp. 316-333, 2013.

[13] K. C. Desouza, Y. Awazu, S. Jha, C. Dombrowski, S. Papagari, P. Baloh, J. Y. Kim, "Customer-Driven Innovation". Research-Technology Management, vol. 51 , no. 3, pp. 35-44, 2008.

[14] S. A. W. Drew, "From knowledge to action: the impact of benchmarking on organizational performance". Long Range Planning, vol. 30, no. 3, pp. 427441, 1997.

[15] H. Elkins, "Does a Managerial Function Differ From a Managerial Role?", Retrieved from https://smallbusiness.chron.com/managerial-function-differmanagerial-role-38713.html, 28.03.2019, 2019.

[16] K. Fichter, "Innovation communities: the role of networks of promotors in Open Innovation", R\&D Management, vol. 39, no. 4, pp. 357-371, 2009.

[17] R. D. Fitjar, A. Rodríguez-Pose, "Firm collaboration and modes of innovation in Norway", Research Policy, vol. 42, no. 1, pp. 128-138, 2013.

[18] H. G. Gemünden, S. Salomo, K. Hölzle, "Role Models for Radical Innovations in Times of Open Innovation", Creativity and Innovation Management, vol. 16, no. 4, pp. 408-421, 2007.

[19] H. G. Gemünden, A. Walter, „Beziehungspromotoren-Schlüsselpersonen für zwischenbetriebliche Innovationsprozesse“, In Promotoren (pp. 111-132). Wiesbaden: Springer, 1999.

[20] R. C. Goduscheit, "Innovation promoters-A multiple case study", Industrial Marketing Management, vol. 43, no. 3, pp. 525-534, 2014.

[21] J. M. Goldberg, H. Schiele, "Innovating with dominant suppliers: Lessons from the race for laser light", International Journal of Innovation Management, vol. 24, no. 01, pp. 2050008, 2020.

[22] J. Hauschildt, "Promotors and Champions in Innovations: Development of a Research Paradigm", The International Handbook on Innovation (pp. 804811). Oxford: Pergamon, 2003.

[23] J. Hauschildt, E. Kirchmann, "Teamwork for innovation - the 'troika' of promotors", $R \& D$ Management, vol. 31, no. 1, pp. 41-49, 2001

[24] Y. He, K. Keung Lai, H. Sun, Y. Chen, "The impact of supplier integration on customer integration and new product performance: The mediating role of manufacturing flexibility under trust theory", International Journal of Production Economics, 147, Part B, pp. 260-270, 2014.

[25] M. Hoegl, S. Wagner, "Buyer-supplier collaboration in product development projects", Journal of Management, vol. 31, no. 4, pp. 530-548, 2005 .

[26] P. Hong, W. J. Doll, E. Revilla, A. Y. Nahm, "Knowledge sharing and strategic fit in integrated product development proejcts: An empirical study", International Journal of Production Economics, vol. 132, no. 2, pp. 186-196, 2011.
[27] J. M. Howell, C. M. Shea, C. A. Higgins, "Champions of product innovations: defining, developing, and validating a measure of champion behavior", Journal of business venturing, vol. 20, no. 5, pp. 641-661, 2005.

[28] L. Hüttinger, H. Schiele, D. Schröer, "Exploring the antecedents of preferential customer treatment by suppliers: a mixed methods approach", Supply Chain Management: An International Journal, vol. 19, no. 5/6, pp. 697$721,2014$.

[29] L. Hüttinger, H. Schiele, J. Veldman, "The drivers of customer attractiveness, supplier satisfaction and preferred customer status: A literature review", Industrial Marketing Management, vol. 41, no. 8, pp. 1194-1205, 2012.

[30] R. Katz, T. J. Allen, "Investigating the Not Invented Here (NIH) syndrome: A look at the performance, tenure, and communication patterns of $50 \mathrm{R} \& \mathrm{D}$ Project Groups”, R\&D Management, vol. 12, no. 1, pp. 7-20, 1982.

[31] E. Kirchmann, "Innovationskooperation zwischen Herstellern und Anwendern“, Wiesbaden: Dt. Univ. Verl. Wirtschaftswissenschaft, 3, 1994.

[32] X. A. Koufteros, G. E. Rawski, R. Rupak, "Organizational integration for product development: the effects on glitches, on-time execution of engineering change orders, and market success", Decision Sciences, vol. 41, no. 1, pp. 4980,2010

[33] M. S. Lambooij, F. Koster, "How organizational escalation prevention potential affects success of implementation of innovations", Electronic medical records in hospitals, Implementation Science, vol. 11, no. 1, 2016.

[34] U. Lichtenthaler, H. Ernst, "The role of champions in the external commercialization of knowledge", Journal of Product Innovation Management, vol. 26, no. 4, pp. 371-387, 2009.

[35] G. S. Lynn, J. G. Morone, A. S. Paulson, "Marketing and discontinuous innovation: the probe and learn process", California management review, vol. 38, no. 3, pp. 8-37, 1996.

[36] M. Maier, P. Rück, A. Brem, „How to Integrate Suppliers into the Innovation Process? An Explorative Case of Champion Formalization in the Purchasing Department in Times of Open Innovation", International Journal of Innovation and Technology Management, vol. 14, no. 06, pp. 1750036, 2017.

[37] Meyer, Meyers großes Taschenlexikon in 24 Bänden (6 ed.). Mannheim: B.-I. Taschenbuchverlag, 1998

[38] M. Primo, S. Amundson, "An exploratory study of the effects of supplier relationships on new product development outcomes", Journal of Operations management, vol. 20, no. 1, pp. 33-52, 2002.

[39] G. L. Ragatz, R. B. Handfield, K. J. Petersen, "Benefits associated with supplier integration into new product development under conditions of technology uncertainty", Journal of Business Research, vol. 55, no. 5, pp. 389400, 2002.

[40] A. Rese, H.-G. Gemünden, D. Baier, “'Too Many Cooks Spoil The Broth': Key Persons and their Roles in Inter-Organizational Innovations", Creativity and Innovation Management, vol. 22, no. 4, pp. 390-407, 2013.

[41] E. Roberts, "Benchmarking global strategic management of technology", Research-Technology Management, vol. 44, no. 2, pp. 25-36, 2001.

[42] K. Rost, K. Hölzle, H.-G. Gemünden, "Promotors or champions? Pros and cons of role specialisation for economic process", Schmalenbach Business Review, vol. 59, no. 4, pp. 340-363, 2007.

[43] R. Rothwell, C. Freeman, A. Horlsey, V. Jervis, A. Robertson, J. Townsend, "SAPPHO updated-project SAPPHO phase II", Research Policy, vol. 3, no. 3, pp. 258-291, 1974.

[44] A. Schieffer, D. Isaacs, B. Gyllenpalm, "The world café: part one”, World Business Academy, vol. 18, no. 8, pp. 1-16, 2004.

[45] H. Schiele, "Early supplier integration: the dual role of purchasing in new product development", $R \& D$ Management, vol. 40, no. 2, pp. 138-153, 2010. 
[46] H. Schiele, "Accessing supplier innovation by being their preferred customer”, Research-Technology Management, vol. 55, no. 1, pp. 44-50, 2012.

[47] D. A. Schon, "Champions for radical new inventions", Harvard Business Review, vol. 41, no. 2, pp. 77-86, 1963.

[48] B. Schültz, "Innovationsförderung durch Promotorenentwicklung", In B. Schültz, P. Strothmann, C. T. Schmitt, L. Laux (Eds.), Innovationsorientierte Personalentwicklung: Konzepte, Methoden und Fallbeispiele für die Praxis (pp. 13-27), Wiesbaden: Springer Fachmedien Wiesbaden, 2014.

[49] M. Song, J. Thieme, "The role of suppliers in market intelligence gathering for radical and incremental innovation", Journal of Product Innovation Management, vol. 26, no. 1, pp. 43-57, 2009.

[50] C. Un, A. Cuervo-Cazurra, K. Asakawa, "R\&D collaborations and product innovation", Journal of Product Innovation Management, vol. 27, no. 5, pp. 673-689, 2010.

[51] S. M. Wagner, "Tapping Supplier Innovation", Journal of Supply Chain Management, vol. 48, no. 2, pp. 37-52, 2012.

[52] A. Walter, H. G. Gemünden, "Bridging the gap between suppliers and customers through relationship promoters: theoretical considerations and empirical results", Journal of Business \& Industrial Marketing, 2000.

[53] L. Williams, S. McGuire, "Economic creativity and innovation implementation: the entrepreneurial drivers of growth? Evidence from 63 countries", Small Business Economics, vol. 34, no. 4, pp. 391-412, 2010.

[54] E. Witte, "Organisation für Innovationsentscheidungen: Das PromotorenModell“, Göttingen: Schwartz, 1973.

[55] E. Witte, "Power and Innovation: A Two-Center Theory", International Studies of Management \& Organization, vol. 7, no. 1, pp. 47-70, 1977.

[56] S.-J. Yoo, O. Sawyerr, W.-L. Tan, "The impact of exogenous and endogenous factors on external knowledge sourcing for innovation: The dual effects of the external environment", The Journal of High Technology Management Research, vol. 26, no. 1, pp. 14-26, 2015. 